\title{
THE JUDICIARY AND NONJUDICIAL ACTIVITIES
}

\author{
ROBERT B. McKaY*
}

The quality and the integrity of the American judiciary has never been higher than today, and judicial sensitivity to ethical considerations continues to rise. But the public seems almost more mistrustful of the legal system in general, and the judiciary in particular, than ever before. How can this be? The explanation is not difficult. The ethical expectations of the public have risen even more rapidly than have the perceptions of the judges of what is now expected of them. Standards of judicial behavior, not seriously challenged when the incumbent was Chief Justice John Jay, John Marshall, or William H. Taft, or during the tenure of many Associate Justices from the earliest to some of the most recent, are no longer acceptable to the legal community, to the public in general, or to the United States Senate. ${ }^{1}$ Presidents Johnson and Nixon learned this lesson the hard way, as did Justice Fortas and Judges Haynsworth and Carswell. ${ }^{2}$ Lower federal courts and state courts have similarly developed more acute perceptions of what is and what is not permissible conduct for members of an appointed or elected judiciary.

The more relaxed standards of yesterday are no longer acceptable. But this relatively abrupt change in attitude creates problems. As a result of this new zeal for a higher ethic in performance of the judicial function, some judges are charged with wrongdoing where there is no fault by any standard, and others are held responsible for failure to meet a standard never before demanded, and only now in the process of formulation. However unfortunate this may be for judges caught in the middle of an evolving ethical standard, the system should benefit from the opportunity to raise standards to a level that contemporary society will not only

- Dean and Professor, New York University School of Law.

Since the subject is ethics, perhaps I should disclose circumstances that may influence my views. At New York University School of Law we rely heavily on the wisdom of several judges who teach as adjunct professors and others who lecture on occasion. The terms of the grant for the distinguished James Madison Lectures specify that the annual lecturer shall be a federal judge or Justice. Judges who are alumni, and some who are not, serve as officers, direcors, and trustees of various Law Centerrelated bodies. Judges register as students in the Appellate Judges Seminars each summer, for which the faculty consists primarily of judges. We have thus relied heavily on judicial talent, not because they accept little or no compensation (although that is true), but because the interchange among judge, lawyer, and law teacher is so valuable-to all three. After this disclosure, I hope you will not find my comments biased, or subject to conflict of interest, and that you will not find it necessary to discount my views.

At least I urge you to examine the Appendix, which was prepared by Mr. Kenneth Bialo, a thirdyear student at New York University School of Law. I assure you that his objectivity is of the same high level as his demonstrated competence.

${ }^{1}$ For a review of significant nonjudicial activities of Justices of the Supreme Court of the United States, many of which would today be considered improper, see the Appendix.

${ }^{2}$ And on April I5, 1970, House Resolution 920, calling for the impeachment of Justice William $O$. Douglas, was referred to the Committee on the Judiciary. II6 Cong. Rec. H3I42 (daily ed. Apr. I5, I970). 
tolerate but demand. ${ }^{3}$ New standards of judicial conduct, now being developed, must satisfy two broad objectives. On the one hand, the standards must be appropriately demanding to the end that justice is facilitated in every possible way. At the same time the standards must ensure that the judges are not unnecessarily separated from the communities they serve in straitjackets of judicial isolation.

The problems have been given too little attention in the past, and they are not easy. But appropriate solutions must be found. The purpose of this discussion is to enumerate some of the questions and to suggest some permissible limits to the nonjudicial activities of sitting judges. Specifically, an effort will be made to differentiate between quasi-judicial activities, which are likely to be tolerated or even encouraged, and extra-judicial activities, which are likely to be forbidden or at most tolerated. I leave to others in the Symposium the related questions of disqualification and conflict of interest, including proposals for disclosure of financial interests. ${ }^{4}$

\section{Some Anctilary Issues of Judicial Administration}

Preliminarily, it is important to establish that definition of the permissible limits for nonjudicial activities is closely related to other issues involving the judiciary and judicial administration. Outside the scope of this paper, or even this Symposium, but inescapably relevant to questions of judicial ethics are at least the following:

I. Selection of judges. So long as most judges outside the federal judicial system are elected on a partisan basis, ${ }^{5}$ necessitating political campaigns and election expense, it is idle to pretend judicial insulation from the most venal of all extrajudicial influence, the favor of the political leader or the momentary passion of the electorate. Nothing is more central to judicial integrity than selection of judges on the basis of merit rather than political preferment.

2. Judicial pay scales. So long as a substantial number of states compensate the judges of their highest courts at less than $\$ 25,000$ per year (often with inadequate retirement plans) and provide even less for judges in the lower courts, ${ }^{6}$ those charged

\footnotetext{
${ }^{3}$ Ethical standards expected of public servants-and of lawyers in or out of public service-are on the rise everywhere. See, e.g., Association of THE BAR of tHE CitY of New York, Confluct of INTEREst and the Federal Service (1960); id., Congress and the Public Trust (1970); ABA Code op Professional ResponstBILITY (approved by the ABA in r969); N.Y. Times, Aug. ro, r970, at 1, col. 8 (demands for a new code of ethics for consultants to the City of New York).

' See Brathwaite, Judicial Misconduct and How Four States Deal with It, 35 LAw \& Contenrp. ProB, I5r (1970); Frank, Disqualification of Jitges: In Support of the Bayh Bill, 35 LAW \& ConTEMP. ProB. 43 (1970); Saeta, Judicial Behavioral Standards from the Perspective of Lower Court Judges, $35 \mathrm{Lnw}$ \& Contemp. Prob. I7I (I970).

${ }^{5}$ Not even federal judicial selections are exempt from partisan considerations, although at least free of the necessity of appeal to electoral whim. In any event, once a federal judge is confirmed, political considerations need not concern him at all.

- Klein \& Clements, Judicial Administration-1969, in 1969/70 ANNuAL SuRveY of AMerrcan Law $603-06$ (1970).
} 
with the drafting or enforcement of ethical standards for judges are likely to remain tolerant of compensation for nonjudicial activities. Ethical sensitivity is not quick to rise above economic need. ${ }^{\top}$

3. Overcrowded calendars. Almost without exception in the large urban centers, and to a surprisingly large extent in more modest-sized communities as well, justice delayed is the rule rather than the exception. Whether the fault lies with permissive rulings on criminal procedure, defective court management, or too few judges, the result is the same. The system is discredited; and the harried judge is less likely to be concerned with the niceties of judicial propriety than with the pressing need to relieve pressure on a crowded docket.

4. Lack of respect for the courts. Large segments of American society are disenchanted, and worse, with the world in which they find themselves. The judicial system is a natural and vulnerable target for the disaffected. When there are complaints about the integrity of judges, suspicion turns into conviction that justice is not to be had in the courts. Disrespect for the courts is taking new and more virulent form in increasingly contemptuous conduct in court and even physical disruption. ${ }^{8}$ Even more alarming is the widely shared mistrust of the judicial system as a whole. It is evident among minority groups, the poor, and even among some of the best educated of our youth who increasingly voice their lack of faith in the courts and in the law itself.

\section{II}

\section{The Function of Ethical Standards}

In general. The standard that will guide the future conduct of judges is clearly not the standard that applied even in the recent past. The nomination of Abe Fortas as Chief Justice of the United States, the withdrawal of the nomination after certain disclosures, his resignation after further disclosures, and the rejection by the Senate of the nomination of Judges Haynsworth and Carswell to the Supreme Court made inevitable the recasting and tightening of previously ill-defined concepts of what conduct is permissible and what is not for judges outside their official duties.

Because the danger of overreaction is severe, ${ }^{10}$ it is important at the beginning

\footnotetext{
${ }^{7}$ This difficulty is particularly acute in the case of part-time judges who must secure part of their income in payment for nonjudicial activities. The comments in this paper are directed primarily to the definition of standards for full-time judges.

${ }^{8}$ For a partial answer see Illinois v. Allen, 397 U.S. 337 (I970). For a more comprehensive response see american College of Trial Lawyers, Report and Recommendations on Disruption of the Judicial Process (1970).

${ }^{\circ}$ It is ironic that the courts seem caught between critics of the right and the left, those who complain that the courts are too activist in their "legislative" judgments and those who argue that the courts are instruments of repression concerned only with upholding the status quo.

${ }^{10}$ The Judicial Conference of the United States, in June of 1969 , demonstrated in classic manner the risk that even the most judicious of all our institutions may act without full attention to consequences. The original decision to forbid virtually all judicial contacts with the outside world was suspended within months and then substantially modified. For a discussion see the text accompanying notes $30-38$ infra.
} 
to consider carefully the interests that are involved and the price that is paid for any limitation upon the outside activities of judges. It would be easy, but intellectually lazy, to hold that the sole business of judges is judging, that all else is at least distracting, and that accordingly a judge should avoid all nonjudicial activities that might either be time-consuming or influence his opinion on matters that come before him. The argument proves too much. If a judge is to live in this world and not in the isolation of a sequestered juror, he is constantly shaping his views on all kinds of matters that may come before him. The perceptions of a judge are influenced by conversations with family, friends, and colleagues; by his choices among the competing news media; his preferences in recreational activities; and even his tastes in clothes and hair styles (the long or short of it).

Skeptics may well charge overkill at this point, for of course no one suggests that judges cut themselves off from family, friends, and colleagues. But anything short of that impossible dream is unlikely to accomplish the objectives of those who seek immunization of the judiciary from all the opinion-shaping forces that surround them. It is at least arguable-and I for one would so argue-that a judge is likely to be a better dispenser of justice if he is aware of the currents and passions of the time, the developments of technology, and the sweep of events. To judge in the real world a judge must live, breathe, think, and partake of opinions in that world. ${ }^{11}$

The dangers of over-involvement in the so-called real world are also great, not only in the perceptions of the public, which are important, but in reality as well. The hazards to guard against are three: (I) participation in outside activities so extensive that the time and energy available for the primary obligation are measurably impaired; (2) participation in out-of-court activities that may lead to actual bias or the appearance of prejudgment of issues likely to come before the court; and (3) actions that impair the dignity and esteem in which the court should be held. Because of the close relationship among these it may be helpful to give examples, which will in turn be refined in the concluding section of this paper with detailed enumeration of the types of quasi-judicial and extra-judicial activities that raise questions of judgment as to permissibility.

By way of illustration. Active participation by judges in the affairs of the day, whether advice to Presidents, service on special legislative or executive commissions, or the more homely tasks of arbitration and partisan political activity, has been accepted as a matter of course until almost the present moment. Justices of the Supreme Court of the United States, surely no less sensitive to judicial proprieties than other judges, have indulged in all these activities-and then some. As the Appendix shows, more than half the Justices who have ever sat on the Court have participated in extensive nonjudicial activities, including many that would now be unacceptable-most without any effort at concealment and without embarrassment, for there was no thought the conduct was wrong.

\footnotetext{
${ }^{21}$ Cf. J. Frank, Courts on Triat (rg49).
} 
Who can doubt that Chief Justice Taft and Justices Brandeis and Frankfurter felt no impropriety in offering advice to Presidents of the United States ? ${ }^{12}$ Surely, each regarded his special role as presidential adviser with a $\mathrm{mwx}$ of obligation and privilege. No one has come forward with supportable evidence of improper influence upon any judicial opinion arising out of these private exchanges. And yet there are few individuals, if any, who will now defend this practice of the recent past. ${ }^{13}$ One wonders why. These and other confidential relationships were never hidden, yet there was no public outcry until the Johnson-Fortas relationship acquired the illsounding sobriquet of "cronyism." Was the practice always ill-advised, or is this but another example of overreaction to a transitory public passion? My speculation is that the public indignation in this case is not transient, but will remain open to ready rekindling if further disclosures should be made in cases not now known. In this instance, at least, the public opinion is correct; the practice of judicial advisement on matters of state ${ }^{14}$ is not tolerable. It is difficult to believe that in a nation of more than 200,000,000 people the President cannot do without the advice of members of the federal judiciary. When President Franklin Roosevelt needed the services of Justice Byrnes as "Assistant President," the Justice resigned from the Court (and none too soon by present standards; during his brief tenure on the Court he regularly advised the President). And when President Lyndon Johnson wanted Justice Goldberg to become Ambassador to the United Nations, Goldberg too resigned. President Truman, however, did it the other-and wrong-way. He nominated Fred Vinson to be Chief Justice, presumably without any thought by either that their close relationship need be interrupted in any way; and apparently it was not.

The surprising fact is that there is little precedent to guide the legislative and judicial hands that are now seeking to define standards adequate for a present that already seems far removed from a chronologically recent past. Federal statutes are not particularly helpful, and the precipitate rulings of the Judical Conference of the United States in 1969 and I 970 provided more confusion than guidance. ${ }^{15}$

\footnotetext{
${ }^{12}$ But see Acheson, Removing the Shadow Cast on the Courts, 55 A.B.A.J. 919 (I969) (including a regretful condemnation by Dean Acheson of Justice Frankfurter, one of Acheson's "closest friends," for his "intimate and notorious friendship" with President Franklin Roosevelt). Acheson conclugded that the relationship "did harm to the public reputation of both the Court and the Justice" despite his confidence that Frankfurter's "friendship with the President did not influence his judicial judgments in any degree." Id. at 921.

${ }^{10}$ In another instance of probable overreaction to the Fortas episode, President Nixon indicated that he would not appoint a close personal or political friend to the Court. N.Y. Times, May 23, $x 969$, at I, col. I. Unless the President's own subsequent interpretation of this statement permits more latitude of choice than at first believed, the President has restricted his freedom of choice to the possible detriment of Court and country. The precedent, if precedent it is, should be avoided.

14 Even more objectionable was the disclosure by Justice Grier to President-elect Buchanan of the likely result in the Dred Scott case before the opinion was announced. See discussion accompanying Appendix note 55 infra.

${ }^{15}$ See text accompanying notes 30-38 infra.
} 
Similarly, state statutes and court rules are generally inadequate. ${ }^{16}$ And the Canons of Judicial Ethics are completely unavailing in their bland counsel in favor of nonspecific virtue and their vague caution against unidentified wrongs. To determine why the legal system has not provided more satisfactory guidance, it becomes necessary to review briefly the limited, and discouraging, history of efforts to identify the permissible limits on nonjudicial activities and then, more hopefully, to examine the prospects for the better day that now seems likely.

III

Legislative and Judicial Regulation of Nonjudicial Activites:

A ReCord of FaILURE

Probably there is universal agreement with the common-sense wisdom of Lord Coke's statement that no man shall be a judge in his own case, ${ }^{17}$ but that standard offers little guidance beyond the conscience of each individual judge. ${ }^{18}$ It was scarcely more useful in the search for fairness in the courts of the eighteenth and nineteenth centuries than when Lord Coke wrote in the seventeenth century.

The earlier more casual views on the permissible range of judicial conduct become more understandable when consideration is given to eighteenth and nineteenth century attitudes about the law, lawyers, and judges. In the early days of the Republic there simply weren't many lawyers, and almost none were trained in university law schools. Accordingly, it is not surprising that most judges were not lawyers and depended for their livelihood principally on income from nonjudicial activities. As the number of lawyers increased in the early decades of the nineteenth century, their prestige plummeted until the nadir was reached during the Jacksonian era. By the middle of the century, many states had removed all requirements for admission to practice on the theory that law, like any other trade, should be open to the competition of the market place. ${ }^{19}$

The first demand for higher standards of professional conduct came from Roscoe Pound in his 1906 speech on "The Causes of Popular Dissatisfaction with the Administration of Justice."20 Moved in part by that speech, the American Bar Association drafted the Canons of Professional Ethics, which were approved in I908; but no separate rules were prepared for judges at that time. Subsequent

\footnotetext{
${ }^{10}$ Recently adopted codes in Illinois and Wisconsin and proposed codes in Florida and Wisconsin are possible exceptions. See the discussion in the final section.

17 Aliguis non debet esse judex inpropria causa. Coke, Instirures *14ra.

${ }^{18}$ Not all think more is necessary. Chief Judge John S. Hastings of the Seventh Circuit has doubted the need or usefulness of detailed regulation. He said: "We have never been happy in our attempts to legislate morality. I suggest, therefore, in applying Canons of Ethics in seeking to achicve a rational course of ethical conduct, the answer is to be found only in the conscience of the judge." Hastings, Iudicial Ethics As It Relates to Participation in Money-Making Activities, in University op Chicago Law School Conference on Judicial Ethics $\pi, 8$ (1965).

${ }^{19}$ Pound, A Hundred Years of American Law, in Law: A Century of Progress 1835-1935, at 8 (Reppy ed. I937). See also C. WARREN, History of THE AMERICAN BAR 532 (I9II).

20 A.B.A. REP. 395 (Part I, x906).
} 
movement was slow, as described in a 1969 report of the American Judicature Society:

[R]esolutions presented at the ABA's Igog and IgI7 conventions calling for the appointment of a committee to draft a set of Judicial Canons were quickly forgotten. Many felt such canons were unnecessary; that the real issue was judicial competency rather than honesty. Others believed it was not the proper role of the Bar to impose standards on the judiciary, feeling that such canons would more appropriately be developed within the judiciary.

It is likely that matters would have rested in this state of inertia for many more years had it not been for the public admission of a certain Federal District Court Judge [Kennesaw Landis] that he was supplementing his $\$ 7,500$ federal salary with $\$ 42,500$ a year for legal services rendered as a national commissioner of the baseball associations. Powerless to bring sanctions against him under the Professional Ethics Canons, delegates attending the I92I ABA Convention could only vote a resolution of censure. ${ }^{21}$

An American Bar Association Committee was then designated to propose standards of judicial ethics. Under the direction of Chief Justice Taft, the committee formulated proposals that were approved by the ABA in 1924 as the Canons of Judicial Ethics. ${ }^{22}$ Since that time official recognition has been given to the Canons in forty-three states, sometimes with local variations. ${ }^{23}$

In 1969 , after several years of study the $A B A$ approved a new Code of Professional Responsibility to replace (and vastly to improve) the Igo8 Canons of Professional Ethics. The next step, now under way, is to formulate new standards of judicial ethics. An ABA Committee on Standards of Judicial Conduct was appointed in 1969. Known as the Traynor Committee, ${ }^{24}$ the body presented its Interim Report, confined to the more controversial aspects of judicial ethics, to the 1970 annual meeting of the ABA in St. Louis. A final report is anticipated in I97I with action by the ABA possible as early as the sumer of 197 .

The American Bar Association has been the pacemaker in the establishment of standards of judicial conduct, and most states have been content to adapt the ABA-proposed Canons to their own needs. Now, however, there is considerable activity by other bodies. Both Congress and the Judicial Conference of the United States have demonstrated increased interest in the development of standards for

\footnotetext{
${ }^{21}$ Amierican Judicature Society, Report No. 8 (June 1969).

${ }^{22}$ It is ironic that Chief Justice Taft, always active in national political affairs, in 1924 continued to offer advice to Secretary of the Treasury Andrew Mellon on which legislation he should urge President Coolidge to veto to secure maximum political advantage. As Taft's biographer concludes, "It is difficult to square Taft's partisan political activity with the canons formulated by the Bar Association's Committee on Judicial Ethics [see Canon 28, Partisan Politics], which Taft himself headed." A. Mason, Wilirans Howard TAFT, ChIEF Justice 283 ( 1965 ).

${ }^{23}$ Kennedy, Non-Judicial Activities of Judges, 5 I Chi. B. Record 64 (1969).

${ }^{24}$ The members in mid-r970 were as follows: Former Chief Justice Roger J. Traynor, chairman; E. Dixie Beggs; Judge Edward T. Gignoux; Judge Ivan Lee Holt, Jr.; Judge Irving R. Kaufman; Professor Robert A. Leflar; William L. Marbury; George H. Revelle; Whitney North Seymour; Justice Potter Stewart. The reporter is Professor E. Wayne Thode.
} 
federal judges. Several state legislatures have enacted legislation, and the highest appellate courts in other states have adopted new codes of judicial conduct.

Curiously, the division of responsibility between court and legislature in the regulation of judicial ethics seems never to have been worked out in any systematic way. The absence of thoughtful analysis of this crucial matter is illustrative of the general inattention to the question of developing standards of judicial ethics. Even at the federal level, where the separation of powers is said to be a principle of constitutional dimension, there is no clear differentiation between what is permitted and what is forbidden to Congress and to Court (or Judicial Conference). Indeed, for most purposes Justices of the Supreme Court and judges of the lower federal courts look to the ABA Canons of Professional Ethics for guidance, even though the Canons have never been specifically made applicable to the federal judiciary except as federal judges are members of the bar of states that have adopted the Canons. Thus, for example, when the propriety of Justice Fortas' nonjudicial activities was questioned, the ABA Standing Committee on Professional Ethics did not hesitate to inquire into possible violation of the Canons or to conclude that there was a "clear violation," citing eight separate canons "bearing on the Fortas question." ${ }^{25}$ Similarly, when the Haynsworth, Carswell, and Blackmun nominations were under consideration, the ABA Standing Committee on the Federal Judiciary, in approving the qualifications of each candidate, reviewed questions of prior conduct in terms of consistency or not with the Canons of Judicial Ethics. ${ }^{28}$

A majority of the Supreme Court has recognized, at least in dictum, that standards of conduct can be imposed on federal judges. ${ }^{27}$ But Congress has dealt with

\footnotetext{
${ }^{25}$ N.Y. Times, May 21, I969, at I, col. 4.

${ }^{20}$ See, e.g., N.Y.L.J., Oct. I4, I969, at I, col. 7 (Haynsworth); id., Apr. 29, 1970, at I, col. 7 (Blackmun).

The lack of differentiation between legislative and judicial responsibility for regulation of judicial conduct is admirably illustrated in Illinois. Rule 63 provides as follows:

"A judge shall not assume an active role in the management of any business or serve as an officer or director of any for-profit corporation. The rule is not intended to prohibit personal investments. If a judge does not neglect his judicial duties in so doing, he may engage in the activities usually incident to the ownership of investment property and may also serve as officer or director of. a not-for-profit corporation. This rule shall become effective January $\mathrm{I}$, 197r."

The odd thing is that this rule deals with the same subject as a 1967 statute, which also becomes effective January $\mathrm{I}, \mathrm{I} 97 \mathrm{I}$. The rule is both more specific in its detailed regulation and more restrictive than the statute. Accordingly, if the rule is valid, which does not seem doubtful, the statute is in effect superseded the very day it becomes effective. Confusion of function and authority must result here as elsewhere until this question is resolved.

${ }^{27}$ In Chandler v. Judicial Council of the Tenth Circuit, 398 U.S. 74, 84-85 (1970), the Court said:

"There can, of course, be no disagreement among us as to the imperative need for total and absolute independence of judges in deciding cases or in any phase of the decisional function. But it is quite another matter to say that each judge in a complex system shall be the absolute ruler of his manner of conducting judicial business. The question is whether Congress can vest in the Judicial Council power to enforce reasonable standards, as to when and where court shall be held, how long a case may be delayed in decision, whether a given case is to be tried, and many other routine matters. As to these things-and indeed an almost infinite variety of others of an administrative nature-can cach judge be an absolute monarch and yet have a complex judicial system function efficiently?
} 
few of the issues, and then not comprehensively. Only three statutes, all in title 28 of the United States Code, are important for present purposes: section I 44 provides for disqualification for "personal bias or prejudice"; section 454 prohibits the practice of law; and section 455 provides for disqualification of a judge in any case in which he has a "substantial interest." Proposals now before Congress would go considerably further, but still do not purport to offer a comprehensive code. Title IV of the Judicial Reform Act ${ }^{28}$ defines conflicts of interest exclusively in terms of financial interest and requires the filing of financial statements. The other principal proposal now before Congress, in the Judicial Disqualification Act of I970, ${ }^{28}$ proposes amendment to section 455 of title 28 (interest of justice or judge) and to section 144 of title 28 (bias or prejudice of judge).

The Judicial Conference of the United States has dealt with questions of ethics at most episodically. Its principal concern has been for the regulation of nonjudicial activities, but here, too, without any suggestion of comprehensive regulation, a matter apparently still left to the American Bar Association. In 1963, for example, the Judicial Conference dealt with a single question, the propriety of service by federal judges as officers or directors of corporations, forbidding such service on for-profit corporations, but allowing continued service with not-for-profit corporations. ${ }^{30}$

On June ro, 1969 , the Judicial Conference, upon the recommendation of its Committee on Court Administration, adopted a resolution prohibiting the acceptance of compensation, whether in the form of loans, gifts, gratuities, honoraria, or otherwise, for nonjudicial services. ${ }^{31}$ The resolution provided, however, that a judge might accept such compensation if, upon application to the judicial council of his circuit $^{32}$ it was determined that the services would not interfere with the judge's judicial duties and would either be in the public interest or were justified by excep-

"Many courts-including federal courts-have informal, unpublished rules which, for example, provide that when a judge has a given number of cases under submission, he will not be assigned more cases until opinions and orders issue on his 'backlog.' These are reasonable, proper, and necessary rules, and the need for enforcement cannot reasonably be doubted. These internal rules do not come to public notice simply because reasonable judges acknowledge their necessity and abide by their intent. But if one judge in any system refuses to abide by such reasonable procedures it can hardly be that the extraordinary machinery of impeachment is the only recourse."

Justices Black and Douglas dissented in separate opinions; the Douglas opinion is particularly sharp in its defense of the freedom of the judge from regulation, at least while doing judicial business, the only issue specifically before the Court. Id. at I29.

${ }^{26}$ S. 1506, 9xst Cong., Ist Sess. (1969).

${ }^{20}$ S. 4201, 91st Cong., $2 \mathrm{~d}$ Sess. (1970).

${ }^{30}$ See Judicial Conference of the United States, Proceedings 55 ( 1963 ). Judges Haynsworth and Blackmun were among the judges who gave up such activities after promulgation of the I963 rule.

${ }^{31}$ Judicial Conference of the Untred States, Proceedings 42 (I969) [hereinafter cited as I969 Proceedrngs]. For a full discussion of this aspect of the work of the Judicial Conference, from which I have drawn extensively, see Ainsworth, Judicial Ethics-The Federal Judiciary Seeks Modern Standards of Conduct, 45 Notre Dame Law. 470 (I970).

${ }^{32}$ The judicial council of each circuit is composed of all the judges of the United States Court of Appeals of the circuit. 28 U.S.C. $\$ 332$ (1964). 
tional circumstances. Where judicial council approval was secured, public disclosure was required of the services rendered and the compensation received.

At the same meeting a second resolution required each judge to file with the Judicial Conference an annual statement of investments and assets held at any time during the year; a statement of income, including gifts and bequests; and a statement of liabilities. The Conference also directed its Committee on Court Administration to begin the formulation of comprehensive standards for the conduct of federal judges, a project never before undertaken or apparently even considered. The risk of concurrent development of inconsistent standards became apparent two months later when the ABA created the Traynor Committee with a mandate similar to that given the Judicial Conference's Committee on Court Administration. The possible conflict was at least postponed, probably removed, when Justice Traynor suggested that the Judicial Conference suspend "any further action on all the resolutions adopted in June ... so that the Conference . . . may have the benefit of the research and work of this Committee."33

The June $I 969$ resolutions of the Judicial Conference were criticized by some lower federal court judges, ${ }^{34}$ by some legal educators, and in some editorials. One widely quoted comment was that of Judge Irving Kaufman, President of the Institute of Judicial Administration, and Professor Delmar Karlen, Director of the IJA. In a letter to the members of the IJA they said on May 28, rg69 (before announcement of the resolutions of the Judicial Conference):

In view of the growing concern about outside activities of judges, we think it important to reaffirm the principle that judges should not become monastic, but should continue to work with the organized bar and the law schools of this country in efforts to improve the administration of justice. Judicial reform is no more a sport for the weak-hearted than it is for the short-winded. If judges should falter now in face of the agitation of the moment, most of the motive power behind court reform would be lost.

When the Judicial Conference met on November I, Ig6g, it modified the earlier resolutions by suspending the requirements of prior judicial council approval and public disclosure. ${ }^{35}$ The Conference also adopted a resolution requiring federal judges to report to the Conference any extra-judicial compensation exceeding $\$ 100$ in any quarterly period. The resolution further provided that the Chief Justice

\footnotetext{
${ }^{33}$ Letter from Roger J. Traynor to Chief Justice Warren E. Burger, Oct. 27, 1969, quoted in Ainsworth, supra note 31 , at 475 .

${ }^{84}$ On the other hand, although the resolutions did not apply to Justices of the Supreme Court, Justices Brennan, Marshall, Stewart, and White announced through Chief Justice Warren their agreement in principle and their intention to act accordingly. Subsequently, seven of the Justices voluntarily filed financial statements consistent with the provisions of the Judicial Conference resolution on that subject. N.Y. Times, Aug. 5, 1970, at 15, col. I. The reports varied from Justice Harlan's statement of no income from off-the-bench activities to Justice Douglas' statement of $\$ 20,568$.10 from lecturcs, articles, and books (royalties accounting for more than half). $I d$.

${ }^{85} \times 969$ Proceedings, supra note $3 x$, at $5 x-52$.
} 
designate a panel of three federal judges to review the reports, which were to be kept confidential except to the extent that the panel concluded that they should be brought to the attention of the Conference. ${ }^{36}$ These resolutions were also criticized, particularly in newspaper editorials which described the modification, particularly the nondisclosure features, as a "retreat."

Finally, on March $18, x 970$, the Judicial Conference announced a further change, reversing the June Ioth resolution that had required federal judges to file annual returns. The new rule requires semiannual statements of income for extra-judicial income in amounts of $\$$ roo or more, including income from lecturing, teaching, and writing. Under this rule federal judges are also required to list gifts worth more than \$roo received by them or any member of their immediate household, as well as any "interests" in parties to cases in which they "knowingly participated."38

During essentially the same period a number of state legislatures, state courts, and state bar association groups investigated the need for revision, usually tightening, of ethical standards. Amended Codes have been adopted in Illinois ${ }^{39}$ and Wisconsin, ${ }^{40}$ and proposals for change are being studied in Florida, Maryland, New Jersey, and New York, among others.

\section{IV}

The Varieties of Nonjudicial Activity: Some Comments ${ }^{41}$

In considering limitations that should be imposed on the nonjudicial activities of judges, the reasons for permission and prohibition should be kept clearly in mind. Although the problem has been discussed before in this paper, it may be useful to summarize, now more briefly, the risks and the benefits.

Nonjudicial activities, whether quasi-judicial or extra-judicial in nature, should not be allowed if there is a substantial likelihood that the undertaking will

I. interfere with the performance of official duty;

2. interfere, or seem to interfere, with the impartiality of the participating judge; or

3. impair the dignity and prestige of the judicial office.

${ }^{30}$ Id. at $5 \mathrm{I}$.

${ }^{37}$ See Ainsworth, supra note 31, at 476. But see City of Carmel-by-the-Sea v. Young, 2 Cal. 3 d 259, 466 P.2d 225, 85 Cal. Rptr. I (I970), invalidating financial disclosure statute as to all investments of public officers, candidates, and their families on the ground of overbreadth.

${ }^{38}$ Chicago Sun-Times, Mar. 19, 1970, at 52, col. I, as cited in Ainsworth, supra note 31, at 476.

${ }^{30}$ See Ill. Ann. Stat. ch. 37, $\$$ I60.I (Supp. I970); Ill. Sup. CT. R. 6I-7T. The new lllinois rules were triggered at least in part by disclosures of impropriety in financial dealings, leading to the resignation in 1969 of two Illinois Supreme Court Justices. See the discussion in Klein \& Clements, supra note 6 , at 608 .

${ }^{10} \mathrm{See}$ In the Matter of the Promulgation of a Code of Judicial Ethics, 36 Wis. $2 \mathrm{~d}$ 252, I53 N.W.2d $873(1967)$.

"I I have been much benefited by the opportunity to examine not only the Interim Report of the Traynor Committee, but as well the annotations of the reporter, Professor E. Wayne Thode. Neither he nor the committee is chargeable with my heresies. 
Where these hazards are not involved, there are reasons to permit, even to encourage, nonjudicial activities if their performance will

I. help to prevent judicial shortsightedness arising from loss of contact with the world outside the court;

2. continue the education and development of essential skills in law and judicial administration; or

3. enrich and educate the audiences to which the judge lectures, writes, or teaches.

Even if these ultimate values are accepted, however, the drawing of lines between virtue and fault in particular instances is by no means an automatic process. The most well-intentioned judge needs standards tested in experience in order to inform his conscience in deciding among alternative courses of conduct. Even though all choices may be equally legal, the appearance of propriety or not may vary considerably from one alternative to another.

To facilitate discussion it should be helpful to differentiate, as does the Traynor Committee, between quasi-judicial and extra-judicial activities. Although some activities in each class should be permitted and some discouraged, the considerations are sufficiently distinct to justify separate analysis.

r. Quasi-judicial activities. This category includes those activities of judges that are not part of their assigned duties, but are related to the judicial function through efforts to improve judicial administration, to accomplish law reform, or to inform other judges, lawyers, or the general public about the nature of law or the substance of its component parts. Although no judge should be required to engage in quasi-judicial activities, the fact is that competent performance of some of the activities identified below is often helpful in bettering judicial performance and increasing public understanding of the judicial function.

a. Lecturing, teaching, and writing. Probably no statute or rule of court categorically forbids teaching, writing, or lecturing on legal, or even nonlegal, subjects. The issue, only recently surfaced, is whether judges can be compensated for their work. The Rules of the Judicial Conference of the United States of June ro, rg6g, later suspended, and still later reversed, ${ }^{42}$ came very close to such a prohibition, permitting the acceptance of compensation only upon a finding by the judicial council of the circuit that the service would be in the public interest or was justified by exceptional circumstances, and that it would not interfere with the performance of judicial duties. Even after the bar was lifted, many federal judges have declined invitations they would otherwise have accepted at law schools and at gatherings of lawyers and judges in a context of continuing legal education. Others, continuing to lecture, to teach, and to write, decline even modest honoraria that are readily available to others for similar service, thus making judges less equal than other lawyers.

${ }^{12}$ See text accompanying notes 30-38 supra. The trigger for the restrictive rule was based in part on the disclosure of the $\$ 15,000$ fee received by Justice Fortas for preparing materials for and teaching a seminar at American University. 
The point requires little elaboration. The simple fact is that good sense seems to have been restored on this point. Similarly, the new Illinois Rules, which categorically forbid compensation "of any kind" for all other nonjudicial activities, specifically exempt "reasonable compensation for lecturing, teaching, writing, or similar activities." 43

The Traynor Committee, after learning that the majority of law schools which responded to a committee questionnaire relied on judges as teachers, lecturers, or moot court judges, concluded in paragraph 2(a) that a judge "may speak, write, lecture, teach, or participate in seminars on matters pertaining to the law and the legal system," and that he could receive "reasonable" compensation as defined in paragraph 7 (Compensation and Expenses) of the Committee report.

The conclusion reached by the Traynor Committee is sound. Judges, lawyers, law students, and the public interest would suffer if these fruitful exchanges were silenced. Judges should not be made second-class citizens.

b. Law reform advocacy. No one is better qualified to speak on law reform and questions of improvement in judicial administration than judges. Even though the efforts necessary to accomplish significant change are often substantial, no barrier should be raised against judicial participation in such activities beyond assurance that the obligations of judicial office are met. A good case could even be made for the proposition that judges have an affirmative obligation to work for improvement in judicial administration. ${ }^{44}$

Canon 23 (Legislation) of the present Canons of Judicial Ethics offers a general license for judges to offer advice on legislative change (presumably including administrative, executive, and judicial reform as well). The rationale of the Canon is that the judge has "exceptional opportunity to observe the operation of statutes, especially those relating to practice, and to ascertain whether they tend to impede the just disposition of controversies . ..."The Traynor Committee recommends more specific treatment, dividing the question of legislative counseling into separate categories that are treated differently.

The Committee would allow a judge to "consult with legislative and executive

\footnotetext{
${ }^{43}$ ILL. Sup. CT. R. 65. The Illinois Supreme Court rejected the recommendation of its drafting committee that would have prohibted all compensation except expenses on this reasoning: "A judge interested in such outside work is unlikely to be doing it for the money; if he is interested in the financial return either the work or the judicial duties should be dropped." Ill. Supreme Court Comm. on Judicini Activities, Report and Reconomendations (comment on Rule 4) (Dec. 4, I969). The Illinois Supreme Court adopted the new Standards for Judicial Conduct on January 30, 1970. Rule 65, Compensation for Nonjudicial Service, is effective January $I$, r 97 I.

In New Jersey, on the other hand, the state constitution forbids judges from engaging in any "gainful pursuit." N.Y. Const. art. 6, §6, \6 (1947). However, a special committee on judicial ethics has recommended that compensation to judges for permissible outside activities, such as teaching, writing, and lecturing be limited to "actual expenses."

"The Wisconsin Code and the proposed Maryland Code impose an obligation on judges to seek improvement of the administration of justice. "A judge should contribute to the public interest by advising, suggesting, and supporting rules and legislation which, from his judicial observation and experience, will improve the administration of justice." WIS. CODE JUD. ETrICs, standard I4.
} 
bodies and officials on matters of judicial administration" [paragraph 2(b)]; but "in drafting legislation and in other activities directed to improvement of the law, the legal profession, and the administration of justice," the recommendation is more restrictive. The Committee would allow participation in the latter activities only "under the auspices of a bar association, judicial conference or other non-partisan organization" [paragraph 2(c)]. The Committee's limitation is intended to prevent "the 'one man' judicial crusade by means of legislative appearances [and to protect] the judge from legislative pressure to appear as an individual and give his views on proposed legislation." As thus explained, the distinction drawn between individual advocacy in relation to judicial administration and group advocacy in other matters of law reform is understandable. But confusion may remain as to the difference between "judicial administration" in paragraph $2(\mathrm{~b})$ and "the administration of Justice" in paragraph 2 (c).

2. Extra-judicial activities. Few if any judges confine themselves to the courtroom, law library, chambers, and the privacy of home. The loneliness and isolation of judicial life, to some extent necessary and desirable, become more tolerable to the kind of person best suited to the bench when coupled with the opportunity to engage in quasi-judicial activities of the kinds suggested above. But the questions do not end there. Few judges, upon accepting judicial office, want to cut themselves off entirely from friends at the bar and in public life or to terminate all private pursuits from which they derived satisfaction. Again the question is to determine which activities and which social or professional relationships may safely be continued without dilution of either the appearance or the reality of full and fair devotion to the cause of justice.

a. Practice of law. Nearly all observers agree now that the private practice of law should be forbidden to full-time judges. ${ }^{45}$ Even so, this represents a change from the standard of Canon 3r of the present Canons of Judicial Ethics which allows private practice where judicial compensation is not "adequate." Uncertainty continues, however, whether a limitation on "private practice" should exclude such related activities as executorships, trusteeships, and arbitration proceedings.

Ordinarily, one would have thought that the perimeters of private practice were fairly well understood. But questions were raised in the case of Justice Fortas whether the $\$ 20,000$ annual fee he first accepted from and then returned to the Wolfson foundation involved the practice of law. He answered that at most he was committed to advice, including but not limited to legal advice. No resolution of the question was reached because Justice Fortas resigned before an answer was required. The question is important, however, because charges have also been advanced against Justice Douglas. If he was engaged in the practice of law, a federal

\footnotetext{
\$5 The administration of justice is no less important when in the hands of part-time judges; but the problems of economics are much more difficult. The Traynor Committee, for example, in its Interim Report, made recommendations only with regard to full-time judges. Perhaps the ultimate solution is to eliminate all part-time judicial positions; but we are not there yet.
} 
"high misdemeanor" has been committed. ${ }^{46}$ His counsel, Simon H. Rifkind, has answered the charge; ${ }^{47}$ but at this writing the committee has not issued its final report.

More troublesome are the subordinate questions as to whether a judge can perform some of the duties often done by lawyers, but which do not necessarily require legal skills, such as executorships, trusteeships, and arbitration proceedings. Canon 27 is vague but generally permissive unless the performance of the duties of an executor or trustee

would interfere or seem to interfere with the proper performance of his judicial duties, or if the business interests of those represented require investments in enterprises that are apt to come before him judicially, or to be involved in questions of law to be determined by him.

The Traynor Committee recommendations are more restrictive, denying fiduciary service "except for the estate or person of a member of his family," and even then with further limitations. ${ }^{48}$ Surely the principle is sound, particularly as softened by the recommendation in paragraph Io(a) of a grandfather clause to permit continued service in a fiduciary capacity by a judge in office when revised rules take effect "if the interests involved and the time demands are not substantial...."

Canon $3^{\mathrm{r}}$ of the Canons of Judicial Ethics authorizes judges to serve as arbitrators for compensation. The Traynor Committee, recognizing that the free-and-easy standard there set forth would not be consistent with other more restrictive rulings of the Committee, concludes that a judge "may serve as an arbitrator only under extraordinary circumstances" (paragraph 9). But why should it be permitted at all? There are no family or personal reasons, as in the limited exception to the rule against fiduciary service; and there is no public interest to be served by having a judge rather than another serve as arbitrator. ${ }^{49}$

b. Business and charitable activities. There is now general agreement that a judge should not, in the words of the Traynor Committee recommendation, "engage in

\footnotetext{
1028 U.S.C. $\$ 454$ (1964).

"First Report by the Special Subcomm. on H.R. Res. 920 of the House Comm. on the Judiciary, 9Ist Cong., 2d Sess. 5I (1970).

${ }^{18}$ The full text of paragraph 4 follows:

"4. Fiduciary Relationships. A judge should not serve as an executor, administrator, trustee, or other fiduciary, except for the estate or person of a member of his family. As a family fiduciary he is subject to the following limitations:

"(a) He should not serve if it is likely that as a fiduciary he will be engaged in any proceedings in his court;

"(b) He should not serve if doing so will divert substantial time from his judicial duties; and

"(c) In administering an estate as a fiduciary, a judge is subject to the same restrictions on financial activities that apply to him in his personal capacity."

10 The American Arbitration Association reported to the Committee that 137 active judges (I33 state and 4 federal) were listed on the Panel of Arbitrators of the Association; but many request no calls while holding judicial office; and in fact only 22 served in the "last year or two," 7 for compensation, I5 without.
} 
business or serve as an officer, director, or advisor of any business organizations" [paragraph 6(a)].0

Many judges serve as officers, directors, and trustees of not-for-profit organizations; many others prefer not to be involved. Most observers would leave the matter where it stands, to the discretion of the individual judge. But there are limits, which are well identified by the Traynor Committee in paragraph 3 of the committee report:

A judge may participate in civic and charitable activities so long as they do not reflect adversely on his impartiality or interfere with fulfillment of his judicial duties. A judge may serve as an offcer, director, trustee, or advisor of a nonprofit organization-educational, religious, charitable, fraternal, or civic-subject to the following limitations:

(a) He should not serve if it is likely that the organization will be substantially engaged in proceedings in his court;

(b) He should not serve if doing so will divert substantial time from his judicial duties;

(c) He should not engage in raising or investing funds, except that he may endorse efforts to obtain funds for an organization devoted to the improvement of the law or the administration of justice. ${ }^{51}$

c. Partisan politics. There is only one possible justification for any judge's involvement in partisan politics. The sad fact is that most judges are still elected and so must participate in the political process at least to the extent necessary to gain and retain office. Appointive judges, including all the federal judiciary, are fortunately separated from the political process upon confirmation and should thereafter have nothing to do with partisan politics, whether by holding party office, participating in election campaigns, endorsing candidates, or soliciting funds. For judges who must seek partisan endorsement and political support, including financial, the problem is more difficult. It is not always easy for a judge to remain aloof from politics because his own position is involved. Nevertheless, in the public interest the prohibition should be as nearly total as possible. When an effective rule against political involvement is stated and enforced, judges should be relieved of many pressures that they must now endure. The Traynor Committee states the principle with admirable succinctness in paragraph 8.

[A judge] should not engage in political activity except to the extent necessarily involved in obtaining or retaining judicial office through an elective political

${ }^{50}$ The reporter's notes, however, indicate that the prohibition was not intended to preclude "ranching or farming as an avocation." What does that mean-permissible so long as the ranch or farm is respectably unprofitable?

"In the solicitation question the new state codes appear to be more restrictive. For cxample, Rulc 4 of the proposed Florida Code provides that a judge "shall not use the prestige of his office for the purpose of raising funds or soliciting favors for any group." Rule 8 of the proposed Maryland Code is a model of directness. "He shall not personally solicit funds for any purpose, charitable or otherwisc." For a more detailed proseription, see ILL. Sup. Cr. R. 64 (c). 
process. A judge may represent his country, state or locality on ceremonial occasions and in connection with educational and cultural exchanges.

Illinois Rule $7^{\circ}$ is more explicit.

A judge shall not (a) hold any official position or office in a political party, shall not serve on any party committee or act as a party leader, and shall not take part in political campaigns except when he is a candidate for elective judicial office; (b) become a candidate for a federal, state or local non-judicial elective office without first resigning his judgeship. A candidate for a judgeship shall not personally solicit or receive campaign contributions, but should establish some method which will not involve him in the direct solicitation of funds.

d. Public service. It has been common in the past for judges to accept appointment to commissions, boards, and other public service positions. The practice has been particularly tenacious at the Supreme Court level where Presidents have frequently drawn upon the prestige of membership on the Court to accomplish some difficult assignment or, more cynically, for personal political advantage. The Appendix shows how common the practice has been at the Supreme Court level, from the occasions on which President Washington sent Chief Justice Jay abroad to negotiate with foreign nations to the instance of President Johnson's insistence that Chief Justice Warren preside at the investigation into the assassination of President Kennedy. These episodes and many others diminished the prestige of the Court; and the result could scarcely have been otherwise. Whenever issues that are highly visible and sensitive are entrusted to a public commission for resolution or recommendation, the results are unlikely to satisfy all the critics, perhaps none. Participation in such a process by members of the judiciary is less likely to settle a troublesome public issue than to lend credence to the all-too-common charge that the courts are part of the political process. The charge becomes hard to deny when five members of the Supreme Court of the United States sit as members of an electoral commission, and each vote is consistent with the advantage of his own party, as happened in 1877 in the Hayes-Tilden dispute.

Even apart from the possible charge of political involvement, if the nonjudicial assignment is important, it requires time and energy, necessarily involving some interference with performance of official duty. Justice Jackson's year-and-a-half absence from the Court when he was the principal prosecutor at Nuremberg was an embarrassment to the Court. Chief Justice Warren's solution in connection with the investigation of the Kennedy assassination was scarcely better when he sought to perform two crucial tasks concurrently. That Warren succeeded as well as he did is a testimonial to his capacity, not to the merit of the idea.

The state codes do not seem to deal directly with the point. The Traynor Committee is also not explicit, although the sense of the recommendations appears to be against such service. ${ }^{52}$

\footnotetext{
${ }^{2}$ Paragraph I emphasizes the primacy of judicial duties to which all other activities are "subordinate."
} 
It should follow inevitably from what has been said above that private counseling. or advice to members of the executive or legislative branches should not be tolerated, whether under the guise of a friendship continued from the past or under the harsher rubric of "cronyism."

e. Personal and social relationships. Apart from bland advice that a judge is entitled to retain pre-court friendships, what can be said that is helpful? Probably not much, but the Traynor Committee in paragraph 5 puts it gracefully, with a minimum of embarrassed posturing, as follows:

A judge should not allow his social relations or friendships to influence, or appear to influence, his judicial conduct. He should not knowingly permit others to trade on the impression that they have special influence with him. He should not testify as a character witness unless he is convinced that his testimony is essential to a just result.

\section{Conclusion}

Chief Justice Roger Traynor, speaking to the Second Circuit Judicial Conference in September I970, said that the ABA Committee on Standards of Judicial Conduct does not aspire to rewrite the Ten Commandments, to annotate the seven deadly sins, or to prescribe a legislative code to forbid judges from hijacking planes, trains, buses, or other means of transportation in interstate commerce. More prosaically, efforts to define standards of judicial conduct should not even be regarded as attempts to legislate morality. The problem is not one of coercing recalcitrant judges with the whip of threatened sanctions. The objective of improved standards is rather to provide guidance for judges who wish to conform to standards that will enlarge public confidence in the judicial process. Judge Irving Kaufman hit the right note, also speaking at the Second Circuit Judicial Conference, when he suggested that a code of judicial conduct asks judges to submit "to ethical dialogues rather than to penal directives."

The definition of appropriate standards of judicial conduct is only part of the task of restoring public confidence in the judicial system. The selection of judges must be removed from politics; judicial pay scales must be made adequate; and delay in the courts must be reduced. While those problems are being overcome, it is important at the same time to advise judges what conduct is expected of them. Some standards will be cast in terms of proscription, even providing sanctions for abuse; but most should be in the form of guidelines to inform the conscience of the judge who wishes to conform his conduct in every respect to the appearance as well as the reality of impartial service to the cause of justice.

Paragraph 2, outlining quasi-judicial activities that are permitted, does not specify executive appointments within the allowed instances. Paragraph 9 allows official representation "on ceremonial occasions and in connection with educational and cultural exchanges," impliedly negating the more substantial commitment required of a working commission. 


\section{APPENDIX}

\section{NONJUDICIAL ACTIVITIES OF JUSTICES OF THE SUPREME COURT OF THE UNITED STATES: A SELECTIVE SUMMARY}

Chief Justice Jay concurrently held the positions of Secretary for Foreign Affairs and Chief Justice for over three months. ${ }^{1} \mathrm{He}$ counseled President Washington and Secretary Hamilton on various matters throughout his tenure. ${ }^{2}$ In I792 Jay ran for Governor of New York State, although he engaged in only a minimum of campaign activities. ${ }^{3}$ Subsequently, Washington appointed him to the diplomatic mission assigned to settle the continuing British-American dispute. ${ }^{4}$ Upon his return Jay resigned from the Court to accept the governorship of New York, a post to which he had been elected in his absence. ${ }^{5}$

Justice Wilson, an important figure at the Constitutional Convention, ${ }^{6}$ devoted considerable attention to various extra-judicial matters while on the Court. $\mathrm{He}$ was a Trustee of the College of Philadelphia and became its first professor of law.? Later he planned to write digests of the laws of the United States and Pennsylvania, but this project was ultimately abandoned. Justice Wilson's extensive business dealings eventually led to disaster; during the 1796 credit squeeze he was "[h]unted like a wild beast" while he rode the circuit.

Justice Samuel Chase campaigned actively on behalf of John Adams, simultaneously ignoring his judicial duties completely. ${ }^{10}$ Chase also played an important role in the passage of the Alien and Sedition Acts. ${ }^{11}$ In I804 the House of Representatives, led by the Jeffersonian Republicans, impeached him as a result of his displays of anti-Republican prejudice in discharging his circuit duties plus his attack on the Jeffersonians delivered in Baltimore in the form of a grand jury charge. The removal attempt ultimately failed in the Senate and Chase remained on the Court until his death in $18 \mathrm{rr} .^{12}$

Chief Justice Oliver Ellsworth was selected by President Adams to voyage to Paris to resolve the disagreements between the United States and France. ${ }^{13}$

\footnotetext{
${ }^{1}$ F. Monaghan, John Jay, Defender of Liberty 300, 304 (1935).

${ }^{2} I d$. at 347 .

${ }^{3}$ Id. at 326,33 I.

Id. at $367-87$.

${ }^{8} I d$. at $405-06$.

${ }^{\circ}$ C. SMith, JaMres WiLson 219-6I, 39I-92 (1956).

7Id. at 308-09.

${ }^{8} 7 d$. at $343-44,35 \mathrm{r}-52$.

${ }^{\circ}$ Id. at 387 .

${ }^{10}$ Dilliard, Samiel Chase, in I The Justices of the United States Supreme Court, $\mathrm{x} 789$-1969, at 185, 193-94 (L. Friedman \& F. Israel eds. 1969) [hereinafter cited as THE Jusnces].

12 Id. at 194.

${ }^{12}$ Id. at 193-97.

${ }^{13}$ W. Brown, The Life of Oliver Ellsworth 273-326 (Ig05).
} 
Justice Washington, while not as politically involved as his colleagues, nevertheless undertook off-the-bench tasks: he served as executor of President Washington's estate ${ }^{14}$ he prepared a four-volume compendium of Third Circuit cases; ${ }^{15}$ and he became the first President of the American Colonization Society, an organization which sought to colonize liberated blacks in Africa. ${ }^{16}$

Chief Justice John Marshall, like Jay before him, was for a time both Secretary of State and Chief Justice. ${ }^{17} \mathrm{He}$ was also an official of the American Colonization Society ${ }^{18}$ As a member of the "Washington Historical Monument Society ... and several literary societies," Marshall cultivated his personal tastes. ${ }^{10}$ In addition, he wrote a biography of George Washington ${ }^{20}$ and was a delegate to the Virginia Constitutional Convention in $1829-30 .{ }^{21}$

Justice William Johnson led an active life off the bench. He served as adviser to President Monroe on federal-state relations ${ }^{22}$ and he utilized his political influence to benefit himself and those close to him. ${ }^{23}$ In 1822 he published a two-volume biography of Nathaniel Greene attempting to accomplish from a Republican point of view the impact that Marshall had achieved in his eariler work on Washington. ${ }^{24}$ $\mathrm{He}$ also wrote the "Philonimus Papers" denouncing those opposed to the broad sweep of the federal treaty power. ${ }^{25}$ Under the pseudonym of "Hamilton," and later in his own name, Justice Johnson issued written replies to the proponents of the Nullification Movement. ${ }^{26}$

Justice Livingston was a member of the Board of Trustees of Columbia University at the time the Dartmouth case was decided. ${ }^{27}$

Justice Thomas Todd was a shareholder in several companies which sought to develop thoroughfares for public travel in Kentucky ${ }^{28} \mathrm{He}$ also held a substantial amount of real property in that state. ${ }^{29}$

While on the Court, Justice Story was active in the affairs of Harvard University: in I818 he became a member of the Board of Overseers ${ }^{30}$ and in 1825 he was elected a Fellow of the Harvard Corporation. ${ }^{31}$ In addition, Story headed an Overseers'

\footnotetext{
${ }^{14}$ Blaustein \& Mersky, Bushrod Washington, in I THE Jostices, supra note ro, at $243,246$.

16 Id. at 247 .

${ }^{10}$ Id. at 256 .

17 II A. Beveridge, The Life of John Marshili 558-59 (I9I6-I9).

${ }^{18}$ IV id. at $473-76$.

${ }^{10}$ Johnson, John Marshall, in I The Justices, sttpra note 10, at 285, 302.

${ }^{20}$ D. Morgan, Justice William Johnson, The First Dissenter 105 (1954).

${ }^{21}$ IV A. BEVERIDGE, supra note $\mathrm{I} 7$, at $472-479$.

22 D. MoRgnN, stupra note 20 , at $123-24$.

${ }^{23} \mathrm{Id}$. at 106-08.

24 Id. at $105-06, \times 48$.

${ }^{25} I d$. at 260 .

${ }^{26} I d$. at $260-64$.

${ }^{27}$ Dunne, Brockholst Livingston, in I THE Justices, supra note xo, at $387,393$.

${ }^{28}$ Israel, Thomas Todd, in I THE Justices, supra note Io, at $407,4 \mathrm{II}$.

${ }^{20} I d$.

${ }^{30} \mathrm{I}$ W. StORY, LiFe AND LetTers of Joseph StORy 444 ( $185 \mathrm{I}$ ).

${ }^{31}$ Id. at 446 .
} 
Committee which laid the groundwork for a comprehensive revision of the administration and curriculum. ${ }^{32}$ But he did not limit himself to such traditional alumnus roles: he became the first Dane Professor of Law. ${ }^{33}$ During his tenure as Professor and Associate Justice, Story published several treatises, covering a broad range of subjects, and a great number of articles in various periodicals. ${ }^{34}$ Earlier he had written an open-ended annotated digest of recent decisions. ${ }^{35}$ Justice Story, however, was not oblivious to political affairs and in I820 he was elected to the Massachusetts Constitutional Convention. ${ }^{36}$ Furthermore, during the Bank debate, he supplied Webster with material for use in his pro-Bank speeches. ${ }^{37} \mathrm{He}$ was also a drafter of statutes, having written portions of federal legislation, ${ }^{38}$ including the Crimes Act of 1825,39 and rendering service on the Massachusetts Codification Commission of $1836-37 .^{40}$

Justice John McLean, long active in church affairs, was named honorary President of the American Sunday School Union in I849.11 McLean never abandoned his ambition to become President of the United States and his name was prominent among those mentioned in pre-convention speculation during the $x 840^{\prime}{ }^{42}{ }^{42}$

Mr. Justice Wayne was an enthusiastic supporter of transportation development in Georgia: in $183^{6}$ he was a local delegate to the Internal Improvement Convention in Knoxville; ${ }^{43}$ later that year he chaired the Georgia State Railroad Convention. ${ }^{44}$ Wayne remained active in state politics and he presided at the 1839 reduction convention. ${ }^{45}$ His foremost intellectual interest was history; he was a corresponding member of the Massachusetts Historical Society and a founder and long-time President of the Georgia Historical Society. ${ }^{46}$

After Roger Taney became Chief Justice, he continued to advise Presidents Jackson and Van Buren on their annual messages to Congress; $;^{47}$ and he counseled Jackson on his Farewell Address. ${ }^{48} \mathrm{He}$ also maintained close contact with local

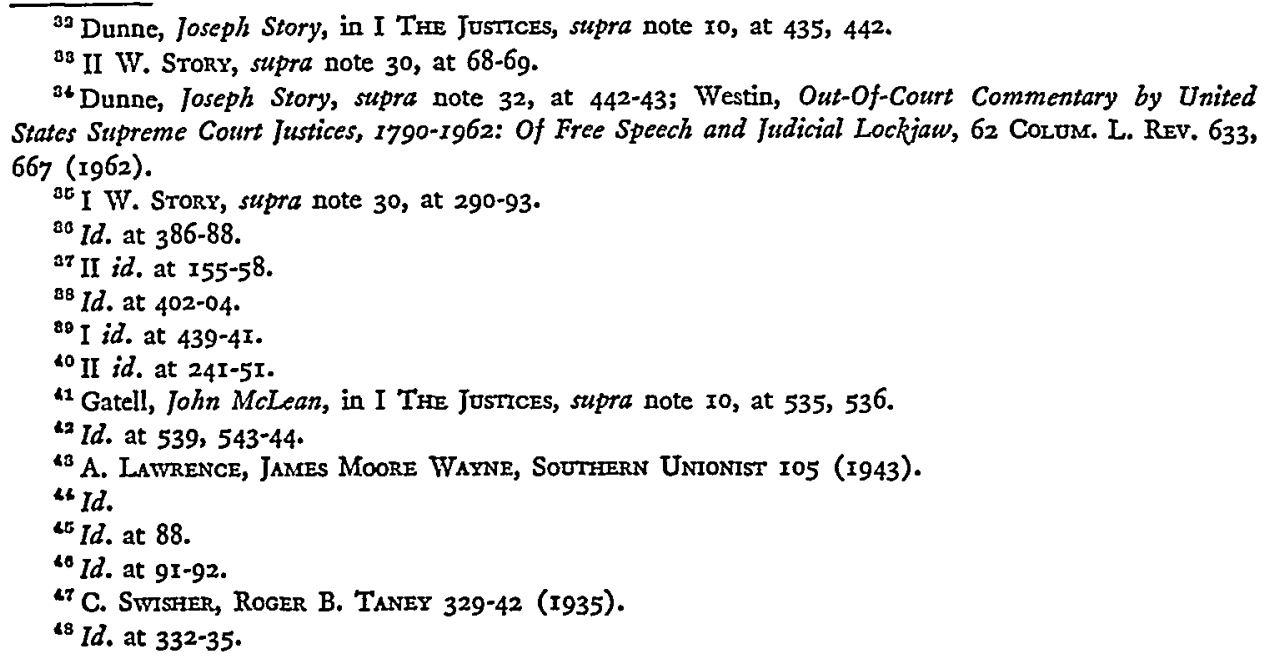


Maryland politics. ${ }^{40}$ In a few instances Taney applied his influence to obtain political appointments for family and friends. ${ }^{50}$

Justice John Catron actively supported James Buchanan in his campaign for the Presidency in $1856 .^{51}$

Justice Nelson was actively involved in national political affairs. In I86I he served as intermediary between Secretary of State William Seward and the Southern commissioners who had come to Washington to seek recognition for the Confederacy. ${ }^{52}$ Ten years later, hoping to help resolve some of the difficulties between the United States and Britain, Nelson accepted an appointment to the Alabama Claims Commission. ${ }^{53}$ The Justice had been discussed in both 1860 and 1864 for the Democratic nomination for President. ${ }^{54}$

Replying to President-elect Buchanan's inquiry regarding the pending Dred Scott case, Justice Grier disclosed both the tenor of the Court conference on Dred Scott and the nature of the emerging majority opinion. ${ }^{55}$

Justice Nathan Clifford was president of the 1877 Electoral Commission. 0

Justice Swayne was active in politics while on the Bench, including vigorous efforts that helped secure passage of the fifteenth amendment in the crucial state of Ohio. ${ }^{\text {b7 }}$

Justice Miller engaged in political maneuvering in an effort to seat his brotherin-law on the Court..$^{58} \mathrm{He}$ was considered by "prominent politicians" for the Presidency in 1880 and 1884,69 and he served as a member of the 1877 Electoral Commission. ${ }^{60}$ Miller was also a prolific author, including three books on the Constitution. ${ }^{61}$

Justice David Davis served as administrator of President Lincoln's estate. ${ }^{02}$ While on the Bench he flirted with the Republican presidential nomination in $1872{ }^{63}$ Five years later he was elected United States Senator by the Illinois Legislature. ${ }^{64}$

Justice Field was involved in partisan politics and he attempted to influence presidential appointments and policies. ${ }^{65} \mathrm{He}$ was also one of the Democrats selected

\footnotetext{
${ }^{\circ}$ Gatell, Roger B. Taney, in I THE Justices, supra note 1o, at 635, 640-4I.

${ }^{60} \mathrm{C}$. Swisher, supra note 47 , at $438-40,458$.

${ }^{61}$ Gatell, John Catron, in I THE Justices, supra note Io, at 737, 745.

${ }^{62}$ Gatell, Samuel Nelson, in II THE Justices, supra note ro, at 817, 825 .

${ }^{83} \mathrm{Id}$. at 828 .

st Id. at 825,827 .

${ }^{5}$ II C. Warren, The Supreme Court in United States History 294-97 (rev. ed. 1932).

${ }^{50}$ Gillette, Nathan Clifford, in II THE Justices, supra note ro, at 963,974 .

57 Gillette, Noah H. Swayne, in II THE Justices, supra note ro, at 989, 997-98.

${ }^{68}$ C. Farrman, Mr. Justice Milleer and The Supreme Court 1862-1890, at 338-72 (1939).

${ }^{60}$ Id. at 293-306.

${ }^{00} I d$. at $280-92$.

61 Westin, supra note 34 , at 666 .

${ }^{62}$ Kutler, David Davis, in II THE Justices, stipra note 10, at 1045, 1053.

${ }^{6 a}$ Id. at 1052.

${ }^{64}$ Id.

${ }^{68}$ C. Swisher, Stephen J. Field, Craftsman of the Law 3r4-20 (7930).
} 
to sit on the 1877 Electoral Commission. ${ }^{66}$ In $x 880$ Field published what has been described as a "campaign autobiography" in the New York Sun. ${ }^{67}$

Chief Justice Salmon Chase earnestly sought the Democratic presidential nomination in $1868 .^{.8}$

Justice Bradley served on the Electoral Commission of I877. While he was the eighth Republican selected, members of both parties believed that his political tenets were of an independent cast and thus it was hoped that he would be capable of rendering a judgment based on the merits of the case. In the end Bradley followed the single course of action that insured victory for the Republican candidate, Rutherford B. Hayes; he voted to certify the Republican state electors for all twenty of the disputed electoral votes. ${ }^{69}$

Justice Harlan accepted a post as one of the arbitrators in the Bering Sea controversy. ${ }^{70}$ During his judicial career he published many books and articles. ${ }^{71}$

Chief Justice Fuller advised Cleveland to run for President in $1892 .{ }^{72}$ As a consequence of Cleveland's victory, Fuller was besieged by requests for assistance in obtaining appointments. ${ }^{73}$ In 1897 he accepted a position on the tribunal created to arbitrate the boundary disagreement between Venezuela and British Guiana. ${ }^{74}$ The following year he refused President McKinley's offer of a position on the Spanish-American War Peace Commission, asserting that "the Chief Justice should not participate in public affairs." 75 The wisdom of that decision proved itself subsequently when the Treaty of Peace came before the Court in the Insular Cases. ${ }^{76}$

Justice Brewer served with Chief Justice Fuller as an arbitrator of the border dispute between Venezuela and British Guiana. ${ }^{77}$ Earlier, Brewer had been president of a congressional committee investigating the situation. ${ }^{78}$ Intellectually active during his tenure, Brewer published a treatise and several articles on a broad range of topics. ${ }^{79}$ In addition, he chaired the Universal Congress of Lawyers and Jurists in $1904:{ }^{80}$ he served as President of the Associated Charities of Washington, ${ }^{81}$ and he was Vice President of the American Society of International Law. ${ }^{82}$

\footnotetext{
${ }^{\circ 0}$ Id. at 271, 273-82.

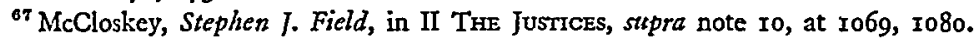

${ }^{08}$ A. Hart, Saldon Portland Chase 361-69 (1899, reprint. I969).

${ }^{\circ 0}$ Friedman, Joseph P. Bradley, in II THE Justices, supra note 1o, at II81, II91-94.

${ }^{70}$ Parker, The Judicial Office in the United States, 23 N.Y.U.L.Q. REv. 225, 237 (I948).

71 Westin, supra note 34 , at 664 .

${ }^{72}$ W. King, Melville Weston Fuller, Chief Justice of the United States 164 (I950).

${ }^{73}$ Id. at $\mathrm{I} 8 \mathrm{I}$,

"Id. at 249.

7t. Id. at $246-47$.

${ }^{70} \mathrm{Id}$. at 247 .

${ }^{27}$ Eitzen, David I. Brewer, 1837-1910: A Kansan on the United States Supreme Court, THE EMPoRIA

State Research Studies, March 1964, at 5, 43.

${ }^{78}$ Id. at 42 .

${ }^{70} \mathrm{Id}$. at $43-44$; Westin, stipra note 34 , at 662 .

${ }^{80}$ Eitzen, stipra note 77, at 44 .

${ }^{81}$ Id. at 47.

${ }^{82}$ Id. at 44 .
} 
While on the bench, Justice William Moody provided President Theodore Roosevelt with memoranda on various topics and with information for speeches. ${ }^{83}$ At Roosevelt's request, Moody and Alfred T. Mahan drafted a plan for reorganization of the Navy which was subsequently adopted by President Taft. ${ }^{84}$

Chief Justice White and Associate Justices Lurton and Van Devanter were members of a committee charged with the task of reviewing and updating the federal rules of equity ${ }^{85}$ White also arbitrated the boundary dispute between Panama and Costa Rica. ${ }^{86}$

Charles Evans Hughes undertook extra-judicial activities during both periods of his Court service. As an Associate Justice he worked on a presidential commission which sought to determine whether second-class postal rates should be retained at current levels. ${ }^{87}$ Furthermore, he was president of the Board of Garfield Memorial Hospital. ${ }^{88}$ While Chief Justice, Hughes was president of the $193^{\circ}$ tribunal arbitrating the Guatemala-Honduras boundary dispute. ${ }^{89} \mathrm{He}$ also wrote extensively. ${ }^{00}$

Justice Van Devanter arbitrated the controversy between Great Britain and the United States resulting from the seizure of the "I'm Alone."01

President Wilson tapped Justice Joseph Lamar for diplomatic assistance when he named Lamar to a commission assigned to conciliate the aggravated relations between the United States and Mexico in Igr $4 .{ }^{92}$

Justice Louis Brandeis furnished advice and assistance to President Wilson on a variety of political issues. ${ }^{93}$ In addition, Brandeis had numerous private interests. Thus, he aided the growth and development of the University of Louisville and enlisted active support from other family members. ${ }^{94}$ Furthermore, he expended considerable effort on behalf of the World Zionist Movement..$^{05}$ For example, after publication of the Shaw Commission Report on the Arab-Jewish riots of 1929, the Justice declared his opposition to the Report's findings to the British Ambassador in Washington. ${ }^{96}$

Justice Clarke became involved in the League of Nations debate and spoke in favor of United States participation. ${ }^{97}$ Subsequently, he resigned from the Court to

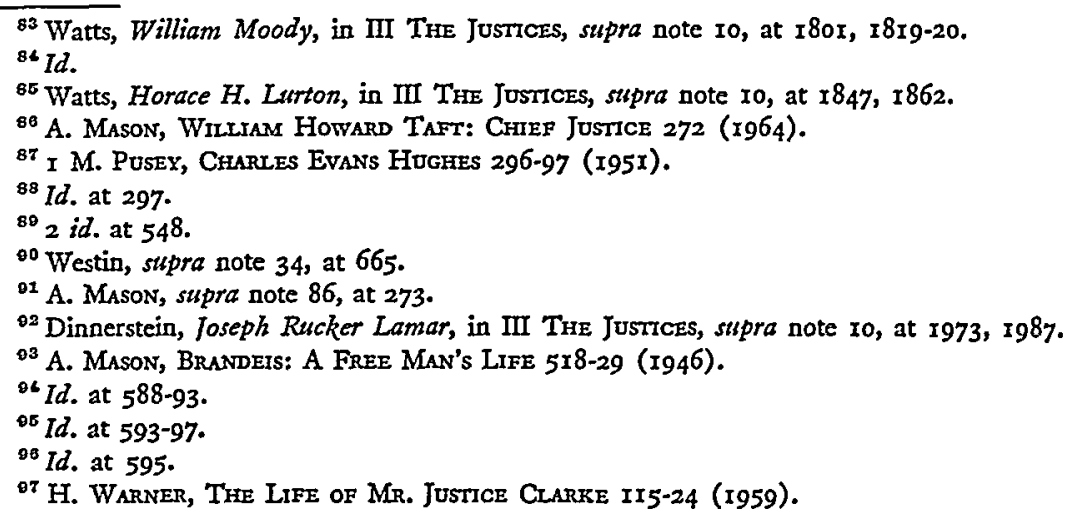


devote all his efforts to the cause. ${ }^{98} \mathrm{He}$ also authored several articles on the Supreme Court and on the judicial power to declare legislation unconstitutional. ${ }^{99}$

Chief Justice Taft's off-the-bench activities were possibly the most extensive in the history of the Court. He was heavily involved in congressional politics and wielded considerable influence on Capitol Hill. ${ }^{100}$ Furthermore, Taft maintained amicable relations with three Presidents and was thus able to influence policy and to voice his views on all candidates for the federal judiciary. ${ }^{101}$ As an active member of the American Bar Association in I922, he headed the committee which drafted the Association's Canons of Judicial Ethics. ${ }^{102}$ In the diplomatic sphere, he voyaged to Great Britain and returned with the suggestion that the English war debt be reduced. ${ }^{103}$ Furthermore, Taft strove earnestly to achieve American participation in the Permanent Court of International Justice. ${ }^{104}$ To this end, he embarked on a secret mission to determine if the United States might join the Court without assuming the obligations of full membership in the League of Nations. ${ }^{105}$ Taft also served as a member of the Board of Trustees of Hampton Normal and Agricultural Institute for Negroes. ${ }^{108}$

Justice Butler was a member of the Board of Trustees of Catholic University of America and a Regent of the University of Minnesota. ${ }^{107}$

Chief Justice Harlan F. Stone advised President Hoover on appointments. ${ }^{108}$ Furthermore, on at least one occasion, he met with Justice Frankfurter and President Franklin Roosevelt to discuss Congress's failure to act on pending military appropriations measures. ${ }^{109}$ Stone's extra-judicial interest did not emphasize political life, however, but rather intellectual pursuits. He was an honorary Associate of Washington's Literary Society, Chancellor of the Smithsonian Institute, Chairman of the Board of Trustees of the National Gallery of Art, and Member of the Board of Trustees of Amherst College. ${ }^{110}$

Justice Owen Roberts was twice selected to serve on presidential commissions. He was a member of the fact-finding body that investigated the events leading up to the Pearl Harbor disaster, ${ }^{111}$ and in 1943 he headed the Commission for the

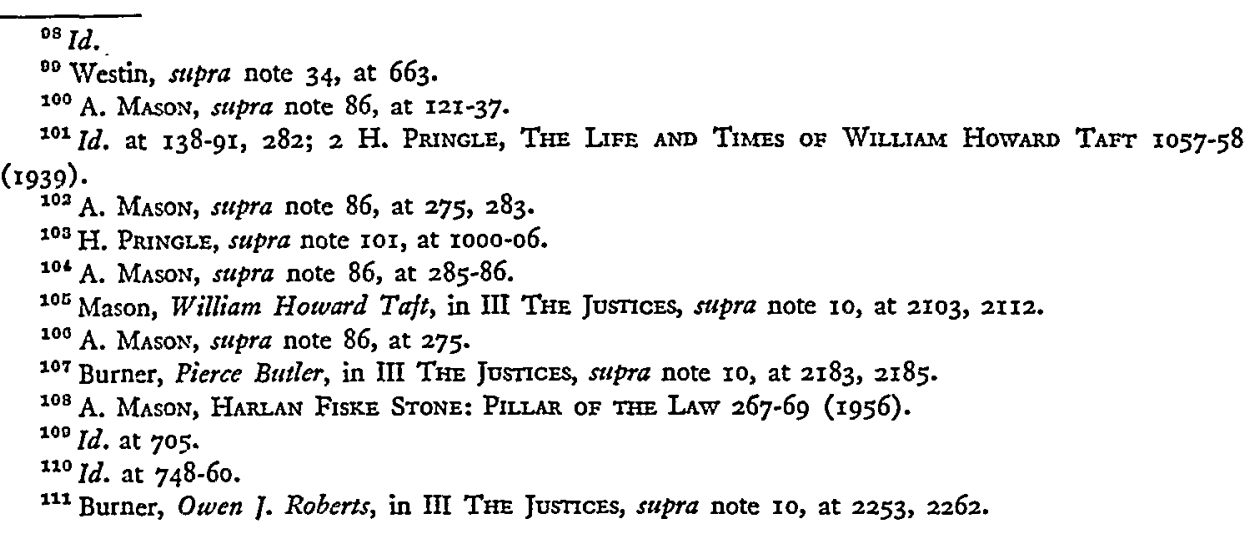


Protection and Salvage of Artistic and Historic Monuments in Europe, a task force charged with cataloguing and tracing art stolen or destroyed by the Nazis. ${ }^{112}$

Justice Reed was Chairman of the Commission on Civil Service Improvement. ${ }^{113}$ Justice Felix Frankfurter furnished President Franklin Roosevelt with a continuing flow of recommendations on domestic and foreign affairs. Topics of their communications ranged from advice on congressional problems and war production to assistance on drafting the proposed Lend-Lease law. ${ }^{114}$ Frankfurter also published copiously. ${ }^{115}$

Justice Douglas wrote more than a score of major books during his first three decades on the Court. ${ }^{116}$ For several years he received "modest compensation" from a private foundation for serving as its director and expending his efforts to recruit foreign students on behalf of American universities. ${ }^{117}$ Furthermore, Douglas has served the Center for the Study of Democratic Institutions in an "executive capacity."118

Justice Byrnes undertook a variety of legislative and political tasks for President Roosevelt. These included drafting emergency legislation, recommending candidates for appointments, and settling disagreements among administrative agencies. ${ }^{119}$ Subsequently, Byrnes resigned from the Court to assume full time duties as the "Assistant President."120

Justice Robert Jackson served as the chief American prosecutor at the Nuremberg Military Trials. ${ }^{121}$ In addition, he published almost a dozen books and articles ${ }^{122}$ and gave numerous lectures, some of which are gathered in a one-volume work entitled The Supreme Court in the American System of Government. ${ }^{123}$

Chief Justice Vinson "remained a part of the Administration" during his time on the Court as he continued to advise President Truman. ${ }^{124}$ Vinson accepted the President's suggestion that he undertake a special diplomatic mission to Moscow, but it was cancelled when Secretary of State Marshall objected. ${ }^{125}$

Chief Justice Warren chaired the presidential commission charged with investi-

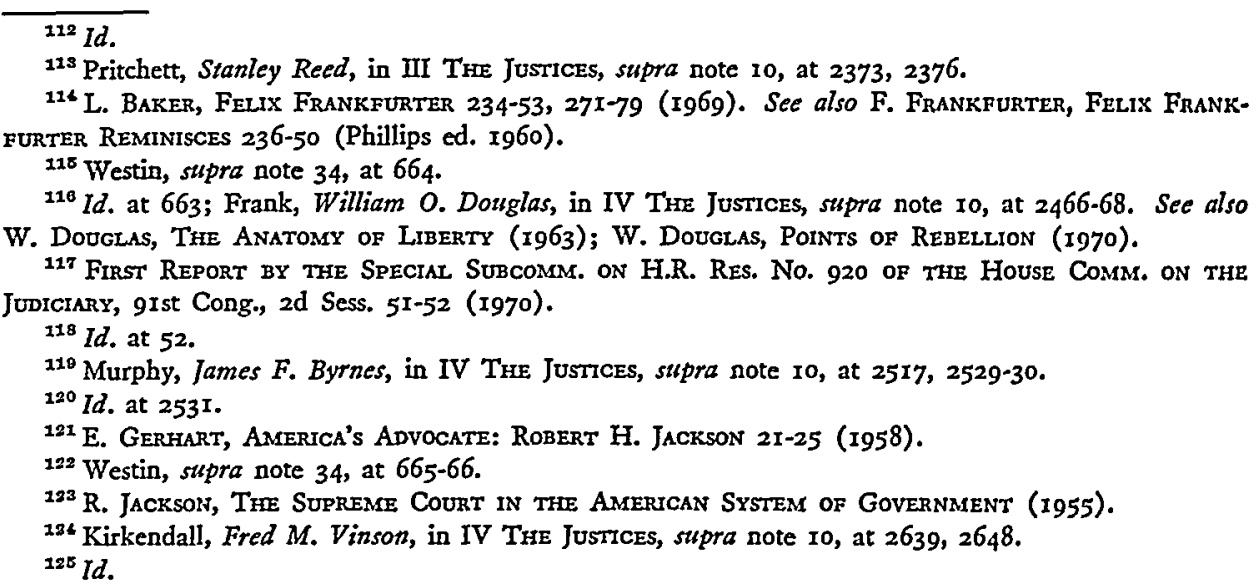


gating the assassination of President John Kennedy. ${ }^{126}$ While on the bench, Warren lectured and wrote extensively. ${ }^{127}$

Justice Brennan lectured extensively and, until r969, participated in the Appellate Judges Seminar held annually at New York University School of Law. ${ }^{128}$ A number of his speeches are collected in An Affair With Freedom. ${ }^{129}$

Justice Potter Stewart is a member of the American Bar Association Special Committee on Standards of Judicial Conduct.

Justice Fortas served as counselor to President Lyndon Johnson and was present at White House crisis meetings on the Vietnam War and the urban disorders. ${ }^{130}$ In addition, he undertook other tasks for the President, such as chastising a presidential critic and assisting in preventing a proposed steel price increase from being implemented. ${ }^{131}$ During the Senate hearings pertaining to Fortas' elevation to the positon of Chief Justice, it was revealed that he had received $\$ 15,000$ for teaching a seminar course at American University during the preceding summer. ${ }^{132} \mathrm{Sub}$ sequently, Life magazine revealed that in 1966 he had accepted $\$ 20,000$ from the family foundation of a man later convicted as a stock manipulator. Although Fortas had returned the first fee, and terminated the arrangement eleven months after it was received, asserting that the burden of his Court work made it impossible to perform the necessary research for the foundation, he resigned from the Court amidst the uproar following the Life story. He disclaimed any wrongdoing, but admitted that under the original contract he would have received $\$ 20,000$ annually for the remainder of his or his wife's life. ${ }^{133}$

Chief Judge Clement Haynsworth, Jr. of the Fourth Circuit Court of Appeals participated in Darlington Manufacturing Company v. $N L R B^{134}$ while he was a part owner, officer, and director of Carolina Vend-A-Matic Company, a corporation which had done business with the appellant. ${ }^{135}$ Alerted to the problem by the objection of an interested attorney, both the Chief Judge of the Fourth Circuit Court and the Justice Department declared Haynsworth was innocent of any wrongdoing. ${ }^{136}$ At the Senate hearings on his nomination to the Supreme Court, it was

\footnotetext{
${ }^{126}$ Report of the Prestdent's Conmission on the Assassination of President John F. Kennedy (1964).

127 Westin, supra note 34 , at 668 .

${ }^{128}$ Edwards, Commentary on Judicial Ethics, 38 Ford. L. REv. 259, 275 (1969).

$120 \mathrm{~W}$. Brennan, AN AfFatr with Freedom (S. Friedman ed. 1967).

${ }^{130}$ Hearings on Nomination of Abe Fortas, of Tennessee, to be Chief Justice of the United States and Nomination of Homer Thornberry, of Texas, to be Associate Justice of the Supreme Court of the United States Before the Senate Comm. on the Judiciary, goth Cong., 2d Sess., pt. I, at 103-06, I25 (1968).

${ }^{131} I d$. at $103-06,167-68,225-29$.

${ }^{132}$ Id., pt. 2, at $1286-308$.

${ }^{133}$ Graham, Abe Fortas, in IV The Justices, supra note ro, at 3015, 3025-27.

${ }^{136} 325$ F.2d 682 (4th Cir. 1963 ).

${ }^{135}$ Hearings on Nomination of Clement F. Haynsworth, Jr., of South Carolina, to be Associate Justice of the Supreme Court of the United States Before the Senate Comm. on the Judiciary, 9Ist Cong., Ist Sess. 2-34 (I969).

${ }^{130} I d$.
} 
further disclosed that for the first six years of his tenure on the bench, Haynsworth had served as an officer and director of several subsidiary companies. ${ }^{137}$ While these facts may have assisted those who opposed his appointment, disciplinary proceedings against the judge were not considered since he had divested himself of these positions pursuant to the 1963 resolution of the Judicial Conference of the United States. ${ }^{138}$

Chief Justice Warren Burger, in the first fifteen months of his service on the Supreme Court, has actively supported law reform and improvement of judicial administration. On August 10, 1970, he made the first State of the Judiciary report to the nation. He also participates in the Appellate Judges Seminar at New York University School of Law.

Following the 1963 resolution of the Judicial Conference of the United States, then-Judge Blackmun disassociated himself from a private for-profit corporation; in doing so he relinquished his $\$ 1,500$ annual fee. ${ }^{130}$ Between 1962 and 1965 he received $\$ 8,500$ for discharging executor's duties. ${ }^{140}$ Supreme Court of the United States Before the Senate Comm. on the Judiciary, 9xst Cong., 2d Scss. 12 (r970).

${ }^{110} \mathrm{Id}$. at $\mathrm{I7}$.
} 